\title{
Fermentation of phytic acid from lamtoro gung seeds (Leucaena leucocephala) to produce inositol and tannin as pharmaceutical commodity
}

\author{
I.A.Rivai Bakti
}

\begin{abstract}
Abstrak
Penelitian mengenai pengaruh berbagai konsentrasi ragi tempe terhadap kandungan inositol dan tanin biji lamtoro gung (Leucaena leucocephala) yang difermentasi telah dilakukan untuk menentukan konsentrasi ragi tempe yang terbaik. Penelitian ini menggunakan rancang acak lengkap (RAL) dengan empat perlakuan dosis ragi tempe masing-masing 0\%, $5 \%$, $10 \%$, dan $15 \%$. Tiap perlakuan diulang empat kali. Data dianalisis dengan analisis varians. Perbedaan nyata diuji dengan uji beda nyata terkecil. Kandungan tanin dianalisis dengan metoda Lowenthal-Procter. Hasil penelitian menunjukkan perlakuan berpengaruh nyata $(P<0,05)$ terhadap parameter yang diukur. Kandungan inositol tertinggi dengan tanin terendah diperoleh pada perlakuan dengan menggunakan ragi tempe dengan dosis $15 \%$ dan waktu fermentasi 96 jam yaitu sebesar 0,2631\%. (Med J Indones 2003; 12: 236-42)
\end{abstract}

\begin{abstract}
The research was done to define the effect of tempe yeast concentration on inositol and tannin contents of fermented lamtoro gung seeds (Leucaena leucocephala). This is a research with completely randomized design using four doses of tempe yeast, i.e. $0 \%$, $5 \%$, $10 \%$, and $15 \%$. Each treatment was replicated 4 times. The resulted data were analyzed by analysis of variance and the significant differences were tested by least significantly difference test. Tannin was analyzed by Lowenthal-Procter method. The result of the research showed that the treatment had significant effects $(P<0.05)$ on the parameter measured. The highest inositol with lowest tannin contents were found by using $15 \%$ tempe yeast and duration of fermentation 96 hours, that is $0.2631 \%$. (Med J Indones 2003; 12: 236-42)
\end{abstract}

Keywords: tempe yeast

The increasing number of population in Indonesia resulted in lack of food and medicine stock material. Therefore, man tries to find alternatives in the form of non conventional materials which have not been fully developed, are easy to obtain, to be processed, and are economically beneficial. One of them is lamtoro gung seed (Leucaena leucocephala). ${ }^{1,2}$ Lamtoro gung seeds content phytic acid and tannin. Lamtoro gung is a multi-function plant. It growths faster than other plants within a year. It begins to bear flowers at the age of 5 to 6 months and the fruit can be harvested every day. The harvest usually reaches 310 to 800 kilograms per acre. ${ }^{1,3}$

Departement of Chemistry, Mathematics and Natural Science, Sriwijaya University, Indaralaya, OKI. South Sumatera, Indonesia
This lamtoro gung is actually in one group with lamtoro which is more popular as petai cina. This plant is originated from Latin America. The shape of the seed is oval and flat. The smell is just like petai cina. The mature seeds are brown-black in colour, hard and waxy. ${ }^{1}$

Lamtoro gung seeds contain equal amount of protein to soya beans. The seed is an energy source and contains mainly phosphor an inositol in the form of phytic acid. The contents depend on the plant species (around 0.82-5.3\%), and found in the form of $\mathrm{K}, \mathrm{Ca}$, $\mathrm{Mg}$ and other metal salts. ${ }^{4}$ Fermentation is one of the ways to increase the inositol contents (Figure 1).

This research aims to know the best dose of tempe yeast in producing inositol from lamtoro gung seeds (Leucaena leucocephala), and to know the best dose of tempe yeast that can reduce the tannin content of lamtoro gung seeds (Leucaena leucocephala). 


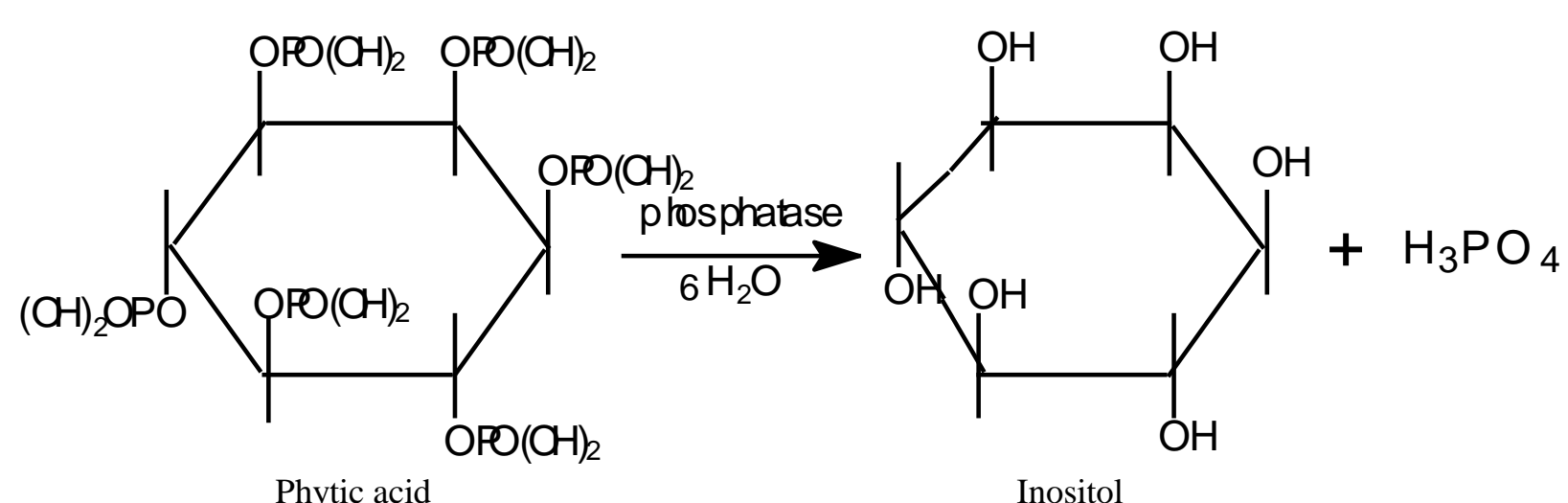

Figure 1. The reaction of phytic acid with phosphatase

\section{METHODS}

\section{Materials}

Lamtoro gung seeds, tempe yeast, sodium-oxalate, aquadest, acidic salt solution, kaolin powder, $12 \mathrm{~N}$ $\mathrm{HCl}$, indigocarmin, gelatin solution, 3\% trichlor acetic acid, $80 \%$ and $90 \% \mathrm{H}_{2} \mathrm{SO}_{4}, \mathrm{~K}_{2} \mathrm{Cr}_{2} \mathrm{O}_{7} .2 \mathrm{H}_{2} \mathrm{O}, \mathrm{KMnO}_{4}$, $\mathrm{FeCl}_{3}$ solution $(1 \mathrm{~N}), \mathrm{L}(+)$ arabinose, inositol standard solutions, $\mathrm{CrCl}_{3} \cdot 6 \mathrm{H}_{2} \mathrm{O}$, phytic acid standard solutions, tannin, betaglucosidase and tempe yeast.

\section{Experiment}

Fermentation time used is 96 hours. Tempe yeast doses were $0 \%, 5 \%, 10 \%$, and $15 \%$ of the sample weight. Each condition was repeated 4 times.

\section{Lamtoro gung seeds fermentation process}

Lamtoro gung seeds (600 grams) were boiled for 2 hours. The boiled seeds were separated from the shells by floating the seeds in water. Then they were soaked in water a night long. After that, they were washed until they were not mucinous anymore, and steamed for 15 minutes. The seeds were dried and refined. We took samples of 10 grams of the refined lamtoro gung seeds, put them into bottles and added yeast to each bottle $(0 \%, 5 \%, 10 \%$, and $15 \%$ of the sample's weight) and pourred $20 \mathrm{~mL}$ of aquadest, then stirred them well. The bottles were closed and kept at room temperature for 96 hours of fermentation.

\section{Reagents used in inositol amount determination}

Solution 1: $0.149 \mathrm{~g} \mathrm{~K}_{2} \mathrm{Cr}_{2} \mathrm{O}_{7} .2 \mathrm{H}_{2} \mathrm{O}$ and $\mathrm{CrCl}_{3} .6 \mathrm{H}_{2} \mathrm{O}$ solved in aquadest to $25 \mathrm{~mL}$.

Solution 2: $1 \mathrm{~g} \mathrm{~L}(+)$ arabinose heated at $100^{\circ} \mathrm{C}$ and diluted to $100 \mathrm{~mL}$ in a tube.

\section{Inositol amount determination}

We put 2 grams of fermented refined lamtoro gung seeds into an Erlenmayer flask, added $40 \mathrm{~mL}$ of $3 \%$ trichlor acetic acid, shaked it up with electric shaker for 45 minutes, and then centrifuged it for 40 minutes. We took $10 \mathrm{~mL}$ of the supernatant and put it to a centrifugation tube and then added $5 \mathrm{~mL}$ of $\mathrm{FeCl}_{3}$ solution, and boiled it for an hour. We centrifuged it for 15 minutes, and took the supernatan out. The sediment was hydrolyzed with $12 \mathrm{~N} \mathrm{HCL}$ at $100^{\circ} \mathrm{C}$ for 6 hours, and then was cooled down. We took 2.5 $\mathrm{mL}$ of the hydrolyzed sediment, put it in a reaction tube, added $0.5 \mathrm{~mL}$ of $80 \% \mathrm{H}_{2} \mathrm{SO}_{4}$ and $0.2 \mathrm{~mL}$ of solution 1. After that, it was shaken carefully, then heated in a water bath for 60 minutes. After cooling down, we added $0.2 \mathrm{~mL}$ of solution 2 and shaked it carefully, added $6 \mathrm{~mL}$ of $90 \% \mathrm{H}_{2} \mathrm{SO}_{4}$, and heated it up in a water bath for 20 minutes. After cooling down, its absorbance was measured at inositol maximum absorbance wave length.

Tannin amount determination (Lowenthal - Procter Method) ${ }^{5}$

We put 5 grams of refined fermented lamtoro gung seeds into an Erlenmayer flask, added $400 \mathrm{~mL}$ of 
aquadest, and boiled it for 30 minutes. After cooling it, we poured it into $500 \mathrm{~mL}$ scaleflask, added aquadest over mark line, and filtered it to make filtrate I. Ten $\mathrm{mL}$ of filtrate I was poured in to Erlenmayer flask. Then $25 \mathrm{~mL}$ of indigocarmyne, $25 \mathrm{~mL}$ of liquid $\mathrm{H}_{2} \mathrm{SO}_{4}\left(12.5 \mathrm{~g} \mathrm{H}_{2} \mathrm{SO}_{4}\right.$ in $250 \mathrm{~mL}$ of aquadest) and 750 $\mathrm{mL}$ of aquadest was added, and titrated with $0.1 \mathrm{~N}$ $\mathrm{KMnO}_{4}$ solution until the color is yellowish-gold. We needed $\mathrm{A} \mathrm{mL}$ of $\mathrm{KmnO}_{4}$ solution.

One hundred $\mathrm{mL}$ of filtrate I was mixed to $50 \mathrm{ml}$ gelatin, $100 \mathrm{~mL}$ acidic salt, and $10 \mathrm{gr}$ kaolin powder. We shaked it up as strong as possible for a minute and filtered it to make filtrate II. We took $25 \mathrm{~mL}$ of filtrate II, added $25 \mathrm{~mL}$ of indigocarmyne solution, $25 \mathrm{~mL}$ of liquid $\mathrm{H}_{2} \mathrm{SO}_{4}\left(12.5 \mathrm{~g} \mathrm{H}_{2} \mathrm{SO}_{4}\right.$ in $250 \mathrm{~mL}$ aquadest) and $750 \mathrm{~mL}$ of aquadest, and titrated with $0.1 \mathrm{~N} \mathrm{KMnO}_{4}$ solution until the color is Yellowish-gold. We needed B $\mathrm{mL}$ of $\mathrm{KMnO}_{4}$ solution $\left(\mathrm{KMnO}_{4}\right.$ solution was standardized by sodium oxalate).

Calculation of tannin content :

$1 \mathrm{~mL} \mathrm{KMnO}_{4}(0.1 \mathrm{~N})=0.00416$ tannin.

$(50 \mathrm{~A}-50 \mathrm{~B}) \times \mathrm{N} / 0.1 \times 0.00416$ The content of tannin $=\frac{}{5} \times 100 \%$

$\mathrm{N}=$ The normality of $\mathrm{KMnO}_{4}$

$\mathrm{A}=$ amount of $\mathrm{KMnO}_{4}$ used for titration $\mathrm{I}(\mathrm{ml})$

$\mathrm{B}=$ amount of $\mathrm{KMnO}_{4}$ used for titration II (ml)

\section{RESULTS}

\section{Inositol}

The analysis results of inositol content in base material are shown in Table 1.

Table 1. Inositol content in base material

\begin{tabular}{cccc}
\hline Repetition & Absorbance & Inositol $(\%)$ & $\overline{\mathrm{X}}$ \\
\hline I & 0.089 & 0.0232 & \\
II & 0.087 & 0.0223 & 0.0230 \\
III & 0.088 & 0.0228 & \\
IV & 0.090 & 0.0237 & \\
\hline
\end{tabular}

The highest inositol content after fermentation was obtained in experiment R3 (experiment dose 15\%). The increase of inositol content in lamtoro gung seeds after fermentation is shown in Table 2.

The analysis results of crude material powder of Lamtoro gung seeds is shown in Table 3.

The results of analysis of tannin content after fermentation is shown in Table 4.

Table 2. Inositol content after fermentation

\begin{tabular}{|c|c|c|c|c|c|c|}
\hline \multirow{2}{*}{ Experiment } & \multicolumn{4}{|c|}{ Result of repetition } & \multirow{2}{*}{ Total } & \multirow{2}{*}{$\bar{X}$} \\
\hline & 1 & 2 & 3 & 4 & & \\
\hline $\mathrm{R} 0$ & 0.0241 & 0.0228 & 0.0282 & 0.0209 & 0.0960 & 0.0240 \\
\hline $\mathrm{R} 1$ & 0.0300 & 0.0295 & 0.0277 & 0.0282 & 0.1154 & 0.0289 \\
\hline $\mathrm{R} 2$ & 0.0542 & 0.0569 & 0.0676 & 0.0636 & 0.2423 & 0.0606 \\
\hline R3 & 0.0890 & 0.0909 & 0.0905 & 0.0932 & 0.3636 & 0.0909 \\
\hline
\end{tabular}

Table 3. Tannin content in base material

\begin{tabular}{cccccc}
\hline Repetition & $\mathrm{A}(\mathrm{ml})$ & $\mathrm{B}(\mathrm{ml})$ & $\mathrm{N}$ & Tannin $(\%)$ & $\overline{\mathrm{X}}$ \\
\hline 1 & 1.82 & 1.70 & 0.0973 & 0.4857 & \\
2 & 1.80 & 1.68 & 0.0973 & 0.4857 & 0.4857 \\
3 & 1.80 & 1.68 & 0.0973 & 0.4857 & \\
4 & 1.82 & 1.70 & 0.0973 & 0.4857 & \\
\hline
\end{tabular}


Tabel 4. Tannin content after fermentation

\begin{tabular}{|c|c|c|c|c|c|c|}
\hline \multirow{2}{*}{ Experiments } & \multicolumn{4}{|c|}{ Result of repetition } & \multirow{2}{*}{ Total } & \multirow{2}{*}{$\bar{X}$} \\
\hline & 1 & 2 & 3 & 4 & & \\
\hline Ro $(0 \%)$ & 0.3238 & 0.4857 & 0.4048 & 0.5667 & 1.7810 & 0.4453 \\
\hline R1 (5\%) & 0.4048 & 0.4857 & 0.2429 & 0.4857 & 1.6191 & 0.4048 \\
\hline R2 (10\%) & 0.2429 & 0.3238 & 0.4248 & 0.3238 & 1.3153 & 0.3288 \\
\hline R3 (15\%) & 0.1619 & 0.2429 & 0.3238 & 0.3238 & 1.0524 & 0.2631 \\
\hline
\end{tabular}

\section{DISCUSSION}

The highest inositol content after fermentation was obtained in experiment R3 (experiment dose $15 \%$ ).

This content increase was caused by the bigger tempe yeast amount that was added to the sample substrate of Lamtoro gung seeds, causing the more enzymes secreted by Rhyzopus $s p$ mold, and the forming of inositol from glucose. This fact suits with Charalapous ${ }^{6}$ statement stating that inositol can be formed from glucose based on enzymatic reaction. Phytic acid is a form of phosphorous and inositol saving in seeds. Phytase is one of the enzymes which is able to let inorganic phosphorous free from phosphate compound through hydrolisation. It can cause the hydrolisation of phytic acid to inositol and free phosphate (orthophosphate or inorganic phosphate) to run faster. Fermentation process can affect the increase of inositol because the existence of Rhyzopus sp in tempe yeast that is able to produce phytase. $^{7}$

Therefore, the high inositol amount in this experiment was caused by Rhyzopus $s p$ that can synthesize phytase in its metabolism. Our result suits Kasmidjo's ${ }^{8}$ statement that Rhyzopus sp mold is the most dominant mold in tempe yeast. Therefore, more phytase is produced. Moreover, lamtoro gung seed is a good substrate for tempe yeast. ${ }^{4}$ Phosphatase can hydrolyze phytic acid in lamtoro gung seeds into inositol.

\section{Inositol}

Inositol is a hexahydroxy siclohexane which can be found in fruits, vegetables, seeds, beans, and milk. ${ }^{9}$ It is stable to heat, acid and alkali. It has a sugar-taste, and is non-hygroscopic. It forms crystal in water or acetic acid above $80^{\circ} \mathrm{C}$. It is non optic-active, and soluble in ether and other organic solvents. ${ }^{10}$
According to Kleiner, ${ }^{9}$ inositol in nature exists in three forms: free inositol, inositol hexaphosphate, and phosphatidil inositol.

Inositol hexaphosphate (phytic acid) in seeds exists in a large concentration due to catalytic hydrogenation of free inositol. As a nutrient, it functions in metabolism as energy source, and plays a role in fat and lipoprotein metabolism and transportation. ${ }^{10}$

Inositol deficiency can cause growth disorder, body swelling and hair thinning. Furthermore, inositol can prevent fat and cholesterol accumulation, and diabetic disease. It is a good subtrate for the growth of microbe, mainly, the digestive system microbe. ${ }^{11}$ Another names of inositol are myo-inositol, mesoinositol, l-inositol, hexahydroxycyclohexane, cyclohexanehexol, cyclohexitol, meat sugar, inosite, mesoinosite, phaseomannite, dambose, nucite, and bios I.

Inositol $\left(\mathrm{C}_{6} \mathrm{H}_{12} \mathrm{O}_{6}\right.$, molecular weight 180.16$)$ is anhydrous, and forms non-hygroscopic crystals in water or acetic acid above $80^{\circ} \mathrm{C}$. It is widely distributed in plants and animals. It acts as growth factor for animals and microorgaisms and can be isolated from heart muscle, and liver. It can be obtained commercially in the form of corn syrup liquor, since inositol is present as phytic acid in corn. It has a sweet taste, and is lipotropic.

Inositol is a significant part of vitamin B $12 .{ }^{11}$ The high concentration of rachitogenic phytic acid in food can be used as inositol derived source of energy for diabetic relief. ${ }^{11}$

Inositolnicotinic compound is an inositol derivative used as vasodilator (200 mg) (Takeda, Winthrop), and as hypolipemic $(400 \mathrm{mg}){ }^{12}$ 


\section{Tannin}

The analysis results of crude material powder of Lamtoro gung seeds is shown in Table 3. They showed that tannin content was $0.4857 \%$. So each acre yielded $0.4857 \times(310$ to $800 \mathrm{~kg})=1.506$ to $3.89 \mathrm{~kg}$ tannin.

Tannin has many synonims, i.e. tannic acid, aretannic acid, gallotannin, gallotannic acid, and incorrectly "digallic acid". Tannic acid of commercial use usually contains about $10 \% \mathrm{H}_{2} \mathrm{O}$. Tannic acid occurs in the bark and fruit of many plants, notably in the bark of the oak species, in sumac and myrobalan. It is produced from Turkish or Chinese nutgall, the former contains $50-60 \%$, the latter about $70 \%$. For the commercial tannic acid, whose specifications follow, the chemical formula is usually given as $\mathrm{C}_{76} \mathrm{H}_{52} \mathrm{O}_{46}$.

Table 3 showed that the fermentation process can decrease tannin content. The color of the fermentation result changes into brown, and the fermentation result has a specific stinging smell.

Tannin is a natural compound which is one of the polyphenol found in plant. It has a lot of hidroxy phenolic group (1-2 for each 100 units's molecule weight), and can build up a stabilizing cross compound with protein and other biopolimers, for example cellulose and pectin. ${ }^{13}$ Based on the structure and it's chemical properties, it is divided into 2 groups: i.e. hydrolyzable tannin (the more important group) and unhydrolyzable tannin (thick tannin, or condensed tannin, or derivative of flavonol).

The hydrolyzable tannins are spread out in the plant tissues. It is amorphous, hygroscopic, yellowishbrown in colour, water soluble (especially in hot water) and forms a colloidal solution. ${ }^{13}$ It is an ester with glycosidic bonds to a monosaccharide, especially $\mathrm{D}$-glucose. The D-glucose is bound to one or more trihydroxybenzencarboxylic acids (its hydroxils are tied with gallic acid, digallic acid and hydroxy diphenic acid). It produces aromatic acid and carbohydrate units, by adding mineralic acid or its salts. ${ }^{14}$ Hydrolyzable tannin is divided into gallotannine resulting gallic acid after hydrolyzation, and elagitannine resulting elagate acid after hydrolyzation. ${ }^{15}$

According to Sjostrom (cited from Fengel, 1995), ${ }^{15}$ condensed tannin is a flavonoid polimer. Its components are catechin (flavan-3-ol) and leucoantocyanidin (flavan-3,4-diol). ${ }^{15}$ The ability of tannin to react with protein can reduce the activities of proteases.

The structure in Figure 2 is that of a tannin named corilagin. The chemical formula of corilagin is $\mathrm{C}_{27} \mathrm{H}_{24} \mathrm{O}_{18}$. Tannin named corilagin will be broken into gallic acid and hexadihydroxy-diphenate by betaglucosidase. ${ }^{13}$
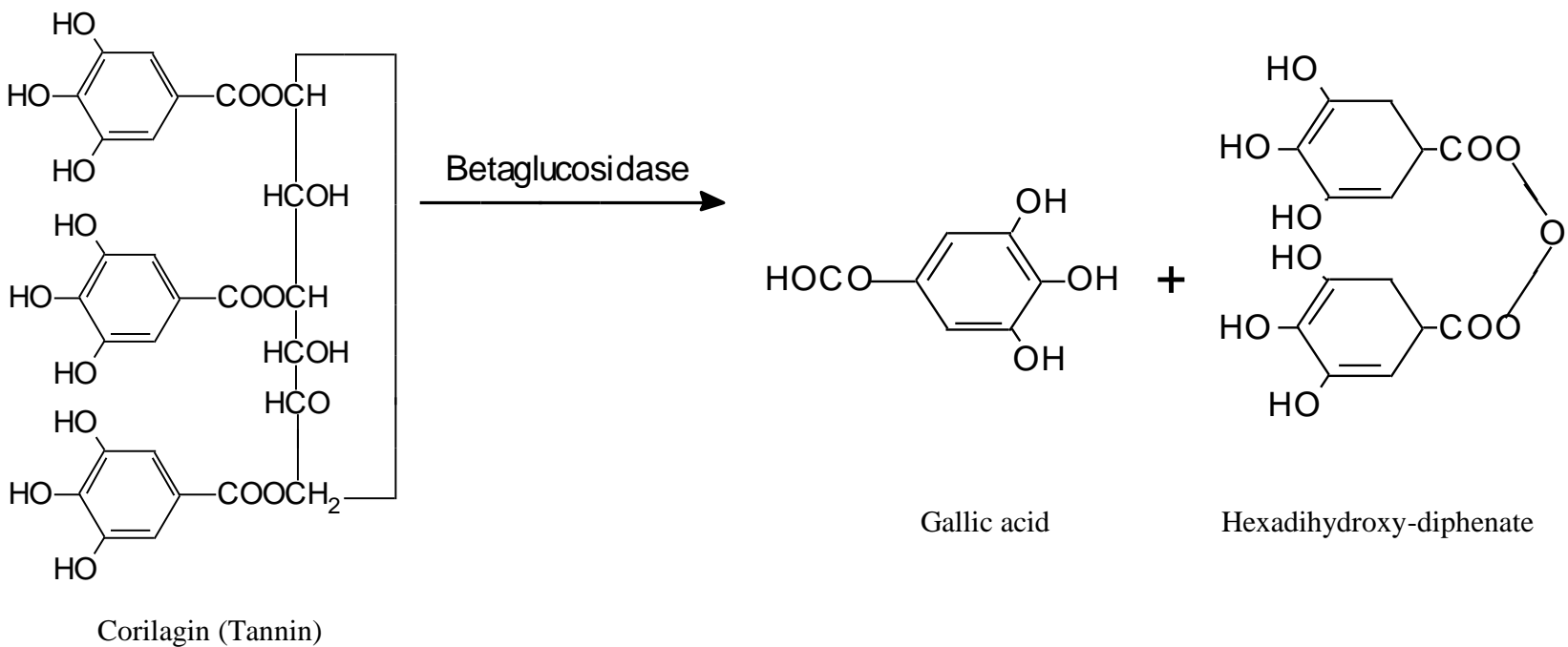

Gallic acid

Hexadihydroxy-diphenate 


\section{Tempe Yeast}

Tempe yeast consists of various species from Rhizopus, Aspergillus, and Mucor genus. In tempe yeast exists some enzymes produced by Rhizopus $s p$, Aspergillus sp. and Mucor sp. ${ }^{16}$ Kasmijo $^{8}$ stated that Rhizopus sp can produce cellulose hydrolyzing enzyme, meanwhile Aspergillus sp produce protease, betaglucosidase, glucoaminase, phytase and lipase. In fermentation, usually the yeast grows well in carbohydrate-containing substrate. Mold from Rhizopus species is the most important microorganism in tempe fermentation. Frequently met in tempe are Rhizopus oryzae, Rhizopus oligosporus, Rhizopus stolonifer and Rhizopus arrhizus. Among the species, Rhizopus orizae, and Rhizopus oligosporus have the main role in tempe fermentation. ${ }^{17}$ Rhizopus is also called bread mold or black mold.

Our results is in line with the result of Marlina et al. Marlina et al indicated that the highest inositol and the lowest tanin contents were obtained by fermentation for 96 hours using tempe yeast. ${ }^{18}$

\section{Phytic acid}

Phytic acid or myo-inositol hexaphosphate exists largely in plants, especially in cereal and leguminaceae. ${ }^{4}$

Phytic acid molecule formula is $\mathrm{C}_{6} \mathrm{H}_{12} \mathrm{O}_{24} \mathrm{P}_{6}$ or $\mathrm{C}_{6} \mathrm{H}_{6}$ $\mathrm{OPO}(\mathrm{OH})_{2}$ with a molecular weight of 660.08 . The chemical name is myo-inositol 1,2,3,4,5,6,- hexosis (dihydrogen phosphate) or myo-inositol hexaphosphate. It is the highest analog to a serial of inositol phosphate that is wide spread in nature. ${ }^{4}$ Phytic acid can affect the process of carbohydrate digestion catalyzed by amylase. It can react with protein to form a complex compound that causes a decrease in the speed of protein hydrolysis done by prosthethic enzymes in the digestive system due to a change in protein configuration. ${ }^{19}$ Phytic acid can be hydrolyzed by phytase to inositol and phosphoric acid. Enzymatic hydrolisis of phytic acid can be done using two kinds of enzymes: first, using phytase in early decomposition to inositol phosphate and inositol diphosphate, and second, using phosphatase in inositol triphosphate dephosphorilation process to inositol monophosphate.

\section{CONCLUSION}

1. In fermentation, yeast increased lamtoro gung seeds inositol content. The best inositol concentration resulted in fermentation was $0.0909 \%$.
2. In the fermentation process of lamtoro gung seeds, tempe yeast concentration was proportionate with the effect of enzyme activities. If the yeast concentration is increased, the enzyme's effect will be higher.

3. In fermentation, yeast decreased lamtoro gung seeds tannin content. The tannin concentration resulted in Ro $(0 \%)$ was $0.4453 \%$, and R1 (5\%) was $0.4048 \%$.

4. The concentration of tempe yeast was proportional with the effect of enzyme activities. If the concentration of tempe yeast was increased the influence of the enzyme was also increased.

5. If we want just phytic acid compound, then we should isolate the raw material of lamtoro gung seeds without using tempe yeast.

\section{Acknowledgments}

We wish to acknowledge Prof. Dr.K.M. Arsyad, DABK, Sp.And, Dean of Medical Faculty, Dr.Fachmi Idris M.Kes., Medical Faculty, and DR.Zulkifli Dahlan MSc. Dean of Mathematics and Natural Science Faculty, Sriwijaya University, Palembang, South Sumatra, Indonesia. The laboratory work and sample collection would not have been possible without their support. Moreover, our deepest gratitude was addressed to local residents at each study area, for conducting the field and laboratory work, and sample collection.

\section{REFERENCES}

1. Suprayitno. Lamtoro gung dan manfaatnya. Jakarta: Bharata Karya Aksara; 1981.

2. Slamet DS. Penelitian pengembangan makanan murah bergizi dari hasil olahan lamtoro gung (Leucaena leucocephala). Bogor: Puslitbang Gizi; 1985.

3. Soerodjotanojo S. Membina usaha perkebunan lamtoro gung. Jakarta: Balai Pustaka; 1983.

4. Noor Z. Senyawa Antigizi. PAU pangan dan gizi. Yogyakarta: UGM; 1992.

5. Sudarrmadji. Analisa bahan makanan dan pertanian. Yogyakarta: Liberty; 1989.p.108.

6. Charalapous F. Encyclopedia of science and technology. New York: McGraw Hill; 1987.

7. Sarwono. Membuat tempe dan oncom. Jakarta: Penebar Swadaya; 1988.

8. Kasmidjo. Tempe-microbiology and biochemstry processing and its benefit. UGM; Yogyakarta: 1990.

9. Kleiner IS. Human of biochemistry. New York: Mosby; 1954.

10. Branen L. Food additives. New York: Marcel Dekker; 1987. 
11. West ES. Textbooks of biochemistry. New York: Mac Millan Co; 1966.

12. Tan, Kirana R. Obat-obat penting, khasiat dan penggunaannya. $3^{\text {rd }}$ ed. Jakarta: Schiedam; 1978.

13. Manitto P. Biosintesa produk alami. Semarang: IKIP Semarang Press; 1992.

14. Robinson $\mathrm{T}$, Padmawinata $\mathrm{K}$. Kandungan tumbuhan tinggi. Bandung: ITB; 1995.

15. Fengel D, Wegener G. Kayu, kimia ultra struktur reaksireaksi. Yogyakarta: UGM Press; 1995.
16. Dwidjoseputro. Dasar-dasar mikrobiologi. $7^{\text {th }}$ ed. Jakarta: Djambatan; 1980.

17. Rahman A. Technology of fermentation. Bogor: Arcan press; 1992.

18. Marlina P, Raudati E, Yudono B. Pengaruh lama fermentasi terhadap kandungan inositol dan tanin biji lamtoro gung (Leucaena leucocephala) [Tesis]. Indralaya: Sriwijaya Univ; 1999.

19. Maurice. Modern nutrition in health and diseases. $8^{\text {th }} \mathrm{Ed}$. Vol I. New York: Waverly Co; 1994. 

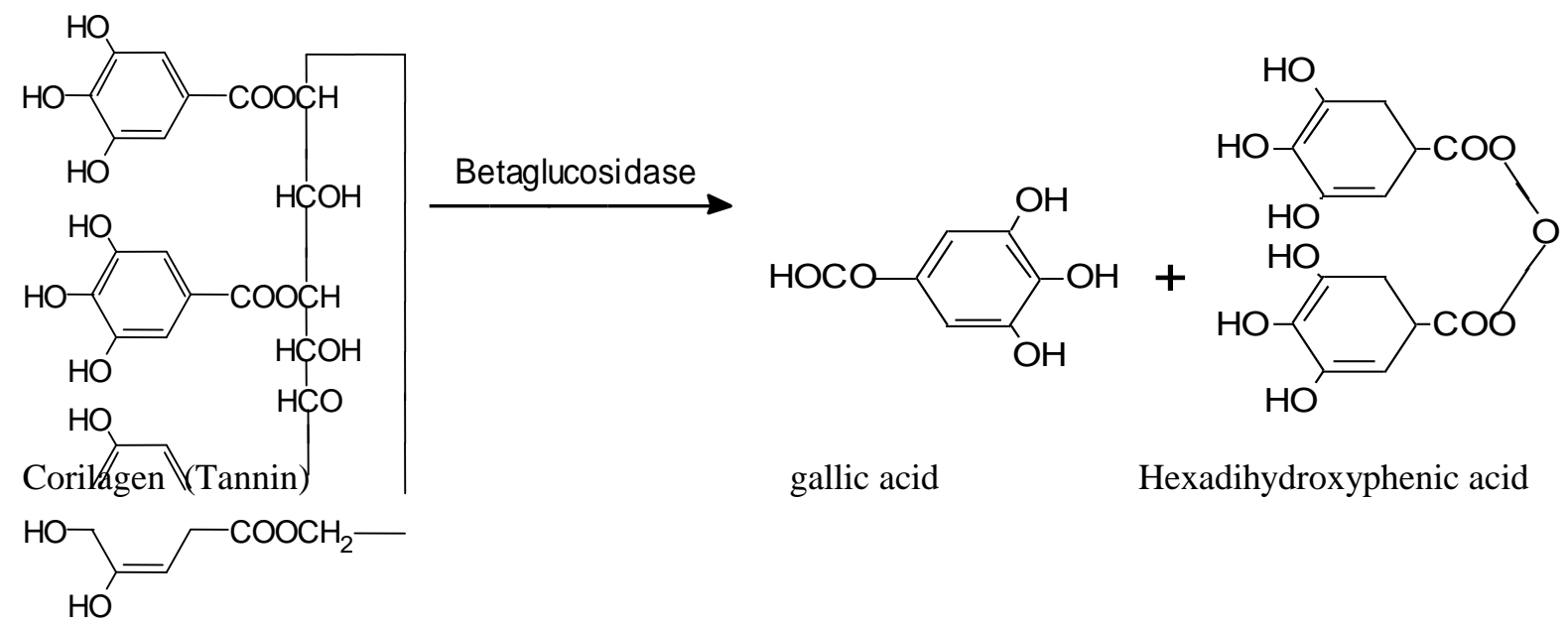

gallic acid

Hexadihydroxyphenic acid

Figure 2. Breaking glucosidic bond of tannin by beta glucosidase 